\title{
Клініко-морфологічна характеристика папілярних карцином щитоподібної залози у пацієнтів, народжених до та після аварії на Чорнобильській АЕС
}

\author{
Б. Б. Гуда, А. Є. Коваленко
}

Інститут ендокринології та обміну речовин імені В. П. Комісаренка НАМН України, м. Київ

\section{Clinico-morphological characteristic of papillary thyroidal carcinomas in patients, born before and after of the Chornobyl AES disaster}

\author{
B. B. Guda, A. E. Kovalenko \\ Komisarenko Institute of Endocrinology and Metabolism of Substances, Kyiv
}

\begin{abstract}
Реферат
Мета. Вивчити частоту папілярних карцином щитоподібної залози з різними характеристиками в залежності від віку пацієнтів з урахуванням дати їх народження - до та після аварії на Чорнобильській AEС.

Матеріали і методи. Проведено ретроспективне дослідження щодо 4956 пацієнтів, оперованих з приводу папілярної карциноми щитоподібної залози в 1995 - 2014 рр.

Результати. Найчастіше пухлини розміром 21 - 40 мм, категорії N1ab i M1, з інвазією в капсулу пухлини, інтра- чи екстратиреоїдною інвазією спостерігали у пацієнтів у віці до 18 років у порівнянні з дорослими пацієнтами, незважаючи на дату їх народження. У дітей та підлітків, народжених після аварії, рідше, ніж у дітей та підлітків, народжених до аварії, реєстрували мультифокальні карциноми та карциноми категорії N1ab.

Висновки. Папілярні карциноми у дітей та підлітків, які народилися до та після аварії на Чорнобильській АЕС, є агресивнішими за папілярні карциноми у дорослих пацієнтів, проте за своїми клінічними характеристиками вони не відрізняються між собою, за винятком меншої частоти мультифокальних карцином і карцином категорії N1ab.

ключові слова: папілярні карциноми; вік пацієнтів; аварія на Чорнобильській АЕС.

Abstract

Objective. To study the thyroidal papillary carcinomas rate with various characteristics, depending on the patients' age, taking into account their birthdate - before and after disaster on Chornobyl AES.

Materials and methods. Retrospective investigation concerning 4956 patients, operated for papillary thyroidal carcinoma in $1995-2014$ yrs.

Results. In the patients, ageing up to 18 years old, comparing with adult patients, and not dependent on their birthdate, most frequent tumors were $21-40 \mathrm{~mm}$ in size, categories N1ab and M1, with tumoral invasion into the capsule, intra- or extrathyroidal invasion were observed. In children and adolescents, born after disaster, less often, than in children and adolescents, born before the disaster, multifocal carcinomas and carcinomas of category N1ab were observed.

Conclusion. Papillary carcinomas in children and adolescents, who were born before and after disaster on Chornobyl AES, are more aggressive, than papillary carcinomas in adult patients, but by their clinical characteristics are similar, excluding lesser rate of multifocal carcinomas and carcinomas of category N1ab.

Keywords: papillary carcinomas; age of the patients; disaster on Chornobyl AES.
\end{abstract}

Незважаючи на те що після аварії на Чорнобильській AEC (далі- ЧАЕС) минуло вже більше ніж 30 років, спостереження раку щитоподібної залози (ЩЗ) привертають до себе досі особливу та постійну увагу як у зв'язку зі значним зростанням захворюваності після радіаційного опромінення населення внаслідок згаданої аваріі [1], так і у зв'язку з існуванням постійного підвищеного ризику виникнення тиреоїдних карцином. Латентний період з моменту дії опромінення до маніфестації захворювання може тривати до 50 - 60 років [2], а надлишковий абсолютний ризик виникнення пухлин збільшується з плином часу [3].

Папілярні карциноми (ПК) ЩЗ, які в перші роки після аварії на ЧАЕС діагностували переважно у дітей і підлітків, характеризувались більшою агресивністю, про що свідчила значна частота пухлин з екстратиреоїдною інвазією та метастазами як у лімфатичні вузли (ЛВ), так і віддаленими $[1,4]$.

Захворюваність на рак ЩЗ у даній групі пацієнтів не знижується дотепер [5, 6]. Більшість пацієнтів, які на момент аварії були дітьми чи підлітками і склали особливу групу підвищеного ризику виникнення ПК, наразі вже пересікла віковий рубіж, який $є$ «класичним» для розвитку спорадичних тиреоїдних карцином - $35-40$ років $[7,8]$. У зв'язку з такою зміною вікової структури онкопатології ЩЗ довготривалий моніторинг за пацієнтами з групи підвищеного ризику, а також динамічний аналіз характеристик карцином і змін їх поширеності у часі є важливими й актуальними. 
Мета дослідження: аналіз частоти ПК ЩЗ з різними характеристиками в залежності від віку пацієнтів з урахуванням дати їх народження - до та після аварії на ЧАЕС.

\section{Матеріали і методи дослідження}

Проведено ретроспективне когортне дослідження щодо 4956 пацієнтів, оперованих з приводу ПК Щ3 в Інституті ендокринології та обміну речовин імені В.П. Комісаренка НАМН України за період з 1995 по 2014 р. У кожного пацієнта проаналізовані вік на момент операції, дата народження, розміри та характеристика пухлини за TNM (використовували 7-му редакцію), клінічна стадія, група ризику, оцінка в балах за шкалою MACIS, кількість курсів радіойодного лікування. Вік хворих становив від 7 до 85 років. У 4547 (91,7\%) пацієнтів виконали тиреоїдектомію, у 1086 (21,9\%) хворих доповнену дисекцією шиї, у 409 (8,3\%) пацієнтів - органозберігаючі операції. Пацієнтів розподілили на групи залежно від віку (на момент операціі) та дати народження. Вони були поінформовані щодо мети дослідження та дали згоду на використання клінічної інформації для дослідницьких цілей.

Дані опрацьовували статистично, використовуючи критерій узгодженості розподілів $\chi^{2}$ Пірсона та пакет комп'ютерних програм «Statistica 12 by StatSoft, Inc.». Критичним рівнем значущості вважали 0,05.

\section{Результати}

Порівнявши частоту ПК ЩЗ у хворих різного віку, ми виявили, що найчастіше пухлини розміром 21 - 40 мм 3 поширеними метастазами у регіонарні ЛВ (категорія N1ab) чи віддаленими метастазами (категорія M1), інвазією в капсулу пухлини, інтра- чи екстратиреоїдною інвазією були у пацієнтів у віці до 18 років (табл. 1). Одночасно у дітей і підлітків найрідше реєстрували мікрокарциноми і неметастазуючі карциноми. 3 підвищенням віку пацієнтів частота агресивніших карцином прогресивно зменшувалася, а мікрокарцином і пухлин категорії NO зростала, проте у хворих у віці старше 60 років у порівнянні з хворими молодшого віку збільшувалася частота ПК розміром понад 40 мм, пухлин категорій N1ab i M1, з екстратиреоїдною інвазією та з мультифокальним характером росту. Частота зазначених пухлин у пацієнтів у віці до 60 років була сталою і не залежала від віку. Частка пацієнтів дитячого та підліткового віку з І стадією хвороби була менша, ніж частка таких пацієнтів у віці 19 - 40 років - відповідно 432 (86,4\%) із 500 пацієнтів та 1941 (97,1\%) із 1998 пацієнтів ( $\mathrm{p}=0,0000)$.

Дослідження залежності частоти карцином щ3 із зазначеними характеристиками від віку хворих потребувало уточнення з огляду на дату їх народження - до чи після аварії на ЧАЕС ( табл. 2). Аналіз частоти ПК з різними характеристиками у групах пацієнтів, які були на момент аварії на ЧАЕС дорослими, дітьми чи підлітками (група ризику щодо отримання певної дози радіаційного опромінення), і пацієнтів, які народилися після аварії на ЧАЕС, показав, що частота ПК з агресивнішими характеристиками у хворих, вік яких на момент операції не перевищував 18 років, не залежить від дати їх народження. Так, у дітей і підлітків, народжених як до, так і після аварії, у порівнянні з дорослими, народженими як до, так і після аварії, реєстрували меншу частоту мікрокарцином, тоді як частота пухлин розміром 21 - 40 мм була більшою. У дітей і підлітків частіше виявляли ПК категоріï N1ab i M1, з інвазією в капсулу пухлини, інтра- чи екстратиреоїдною інвазією, з мультифокальним характером росту. Відповідно було більше у порівнянні з дорослими пацієн-

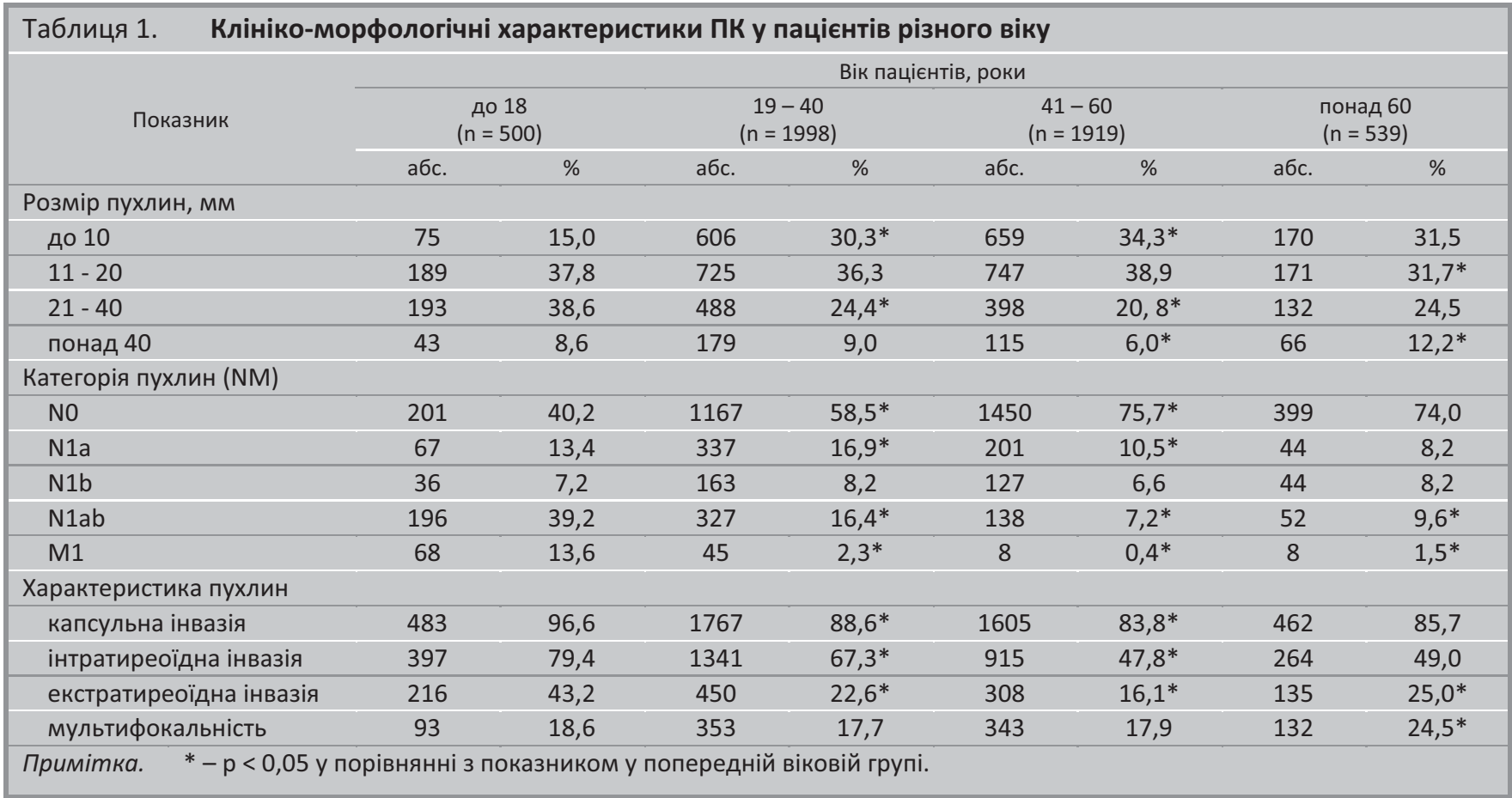




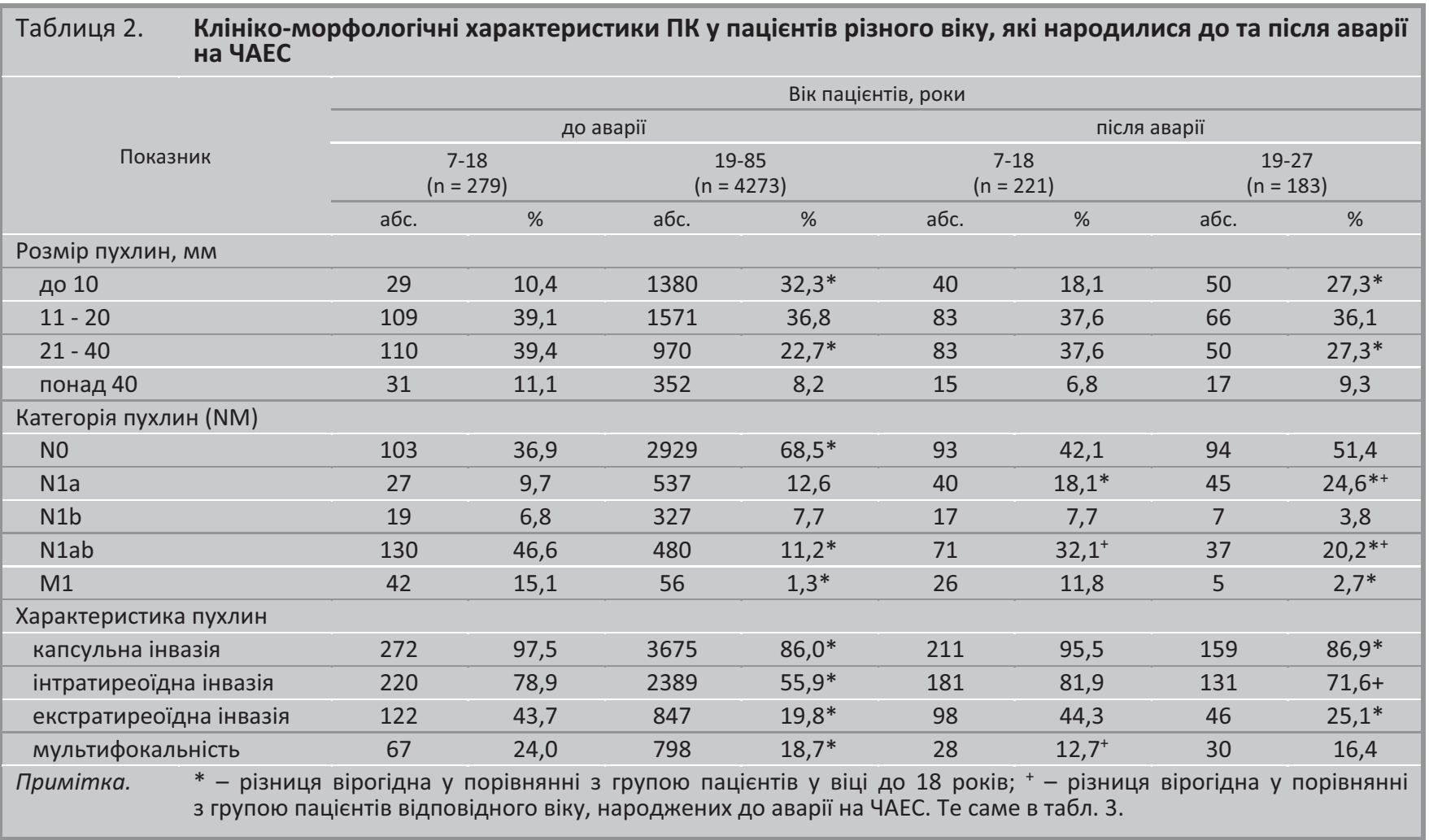

\begin{tabular}{|c|c|c|c|c|c|c|c|c|}
\hline Таблиця 3. & \multicolumn{8}{|c|}{$\begin{array}{l}\text { Клініко-онкологічна характеристика ПК у пацієнтів різного віку, які народилися до та після аварії } \\
\text { на ЧАЕС }\end{array}$} \\
\hline \multirow{4}{*}{ Показник } & \multicolumn{8}{|c|}{ Вік пацієнтів, роки } \\
\hline & & \multicolumn{3}{|c|}{ до аварії } & \multicolumn{4}{|c|}{ після аварії } \\
\hline & & $\begin{array}{c}7-18 \\
(n=279)\end{array}$ & \multicolumn{2}{|c|}{$\begin{array}{c}19-85 \\
(n=4273)\end{array}$} & \multicolumn{2}{|c|}{$\begin{array}{c}7-18 \\
(n=221)\end{array}$} & \multicolumn{2}{|c|}{$\begin{array}{c}19-27 \\
(n=183)\end{array}$} \\
\hline & абс. & $\%$ & абс. & $\%$ & абс. & $\%$ & абс. & $\%$ \\
\hline \multicolumn{9}{|l|}{ Стадія хвороби } \\
\hline 1 & 237 & 84,9 & 3252 & $76,1^{*}$ & 195 & 88,2 & 178 & $97,3^{*+}$ \\
\hline II & 42 & 14,7 & 290 & $6,8^{*}$ & 26 & 11,8 & 5 & $2,7^{*+}$ \\
\hline III-VI & - & - & 731 & 17,1 & - & - & - & - \\
\hline \multicolumn{9}{|l|}{ Ризик } \\
\hline дуже низький & 26 & 9,3 & 1029 & $24,1^{*}$ & 18 & 9,1 & 29 & $15,8^{*+}$ \\
\hline низький & 51 & 18,3 & 1475 & $34,5^{*}$ & 54 & 24,4 & 55 & 30,1 \\
\hline високий & 202 & 72,4 & 1769 & $41,4^{*}$ & 149 & 67,4 & 99 & $54,1^{*+}$ \\
\hline \multicolumn{9}{|l|}{$\begin{array}{l}\text { Кількість курсів } \\
\text { радіойодтерапії }\end{array}$} \\
\hline 1 & 175 & 62,7 & 3486 & $81,6^{*}$ & 144 & 65,1 & 141 & $77,0^{*}$ \\
\hline 2 & 36 & 12,9 & 254 & $5,9^{*}$ & 18 & 8,1 & 16 & 8,7 \\
\hline 3 і більше & 51 & 18,3 & 129 & $3,0 *$ & 40 & 18,0 & 4 & $2,2^{*}$ \\
\hline \multicolumn{9}{|l|}{ MACIS (бали) } \\
\hline менше 5,99 & 234 & 83,9 & 3780 & $88,5^{*}$ & 196 & 88,7 & 177 & $96,7^{*+}$ \\
\hline $6-6,99$ & 10 & 3,6 & 304 & $7,1^{*}$ & 2 & 0,9 & 2 & $1,1^{+}$ \\
\hline $7-7,99$ & 16 & 5,7 & 106 & $2,5^{*}$ & 11 & 5,0 & 2 & $1,1^{*}$ \\
\hline більше 8 & 19 & 6,8 & 83 & $1,9 *$ & 12 & 5,0 & 2 & $1,1^{*}$ \\
\hline
\end{tabular}

тами дітей і підлітків, які мали II стадію хвороби чи входили до групи високого ризику (табл.3). Для ефективного лікування пацієнтам віком до 18 років частіше було потрібне проведення більше одного курсу радіойодтерапії. Так, два і більше курсів радіойодтерапії було про- ведено 87 (31,2\%) із 279 дітей, народжених до аварії, і 383 $(9,0 \%)$ із 4273 дорослих ( $\mathrm{p}=0,0000)$, а народженим після аварії - відповідно 58 (26,2\%) із 221 і 20 (10,9\%) із 183 (р = 0,0001). Частіше діти та підлітки мали гірші прогностичні показники за системою MACIS. Так, прогноз було оці- 
нено в 7 балів і більше у 35 (12,5\%) із 279 дітей, народжених до аварії, та у 189 (4,4\%) із 4273 дорослих пацієнтів ( $\mathrm{p}=0,0000)$, а у народжених після аварії - відповідно у 23 $(10,4 \%)$ iз 221 i $4(2,2 \%)$ iз $183(\mathrm{p}=0,0009)$.

\section{Обговорення}

Результати аналізу даних щодо розподілу ПК з різними характеристиками в дослідженій когорті засвідчили у двох вікових категоріях - до 18 років (особливо) і старше 60 років - більшу частоту агресивніших ПК. Висновок щодо агресивності ПК у дітей та підлітків збігається з даними, отриманими в інших дослідженнях, де показано, що ПК у дітей метастазують у ЛВ та віддалено [9]. Загалом у дітей та підлітків у порівнянні з пацієнтами віком від 20 до 30 років захворювання, як правило, має негативнішу клінічну картину [10 - 12] навіть тоді, коли немає метастазів [9]. Остання теза підтверджена і нашими даними щодо меншої частки пацієнтів дитячого та підліткового віку з І стадією хвороби у порівнянні з таким показником для хворих у віці 19 40 років. Незважаючи на це, виживаність пацієнтів віком до 18 років є стовідсотковою, але зменшується з віком і щодо хворих у віці старше 60 років дворічна виживаність становить 95,2\%, двадцятирічна - 86,1\% [13].

Отже, у дітей і підлітків, незалежно від того, коли вони народилися відносно дати аварії на ЧАЕС, частіше реєстрували агресивніші ПК. Цей висновок збігається з результатами досліджень характеристик «радіогенних» і «спорадичних» ПК: прояви агресивності пухлини були найчастішими у дітей у порівнянні з дорослими пацієнтами незалежно від ії етіології [14].

Водночас у пацієнтів віком до 18 років, народжених після аварії, ми рідше реєстрували мультифокальні ПК та ПК категорії N1ab і частіше ПК категорії N1a у порівнянні з пацієнтами того ж віку, що народилися до аварії і входили до групи ризику. Раніше було показано, що в осіб, які народилися після аварії на ЧАЕС, частіше виявляли мікрокарциноми і рідше пухлини з метастазами в ЛВ і віддаленими метастазами [4]. Слід зазначити, що у згаданій роботі групи пацієнтів, народжених до та після аварії, мали різний вік - відповідно 20-40 років та 11 - 22 роки, крім того, термін спостереження (період, у якому ці хворі були прооперовані) був обмежений 2006 - 2008 рр. Отримані нами дані збігаються з висновками інших дослідників: «Попри ранні повідомлення про те, що рак ЩЗ, який виник у дітей після аварії на ЧАЕС, був особливо агресивним, тепер здається, що презентація та клінічний перебіг у більшості з цих спостережень дуже схожі на «нерадіаційний» рак щитоподібної залози» [15].

Звертає на себе увагу те, що частота ПК категорії N1 ab і пухлин з інтратиреоїдною інвазією виявилася вищою у дорослих пацієнтів, народжених після аварії, у порівнянні з пацієнтами, які були дорослими на момент аварії на ЧАЕС, чого ми не спостерігали у дітей та підлітків ( 2). Незважаючи на те, що пацієнти, народжені після аварії, частіше мали I стадію хвороби та кращий прогноз за системою MACIS, частка тих, які входили до групи з висо- ким ризиком рецидиву, була вищою (табл.3). Водночас слід зазначити, що вік пацієнтів, які народилися після аваpiї і на момент виконання оперативного втручання були дорослими, обмежений з об'єктивних причин 27 роками, а в групу пацієнтів, які були дорослими на момент аварії, увійшли пацієнти віком 19 - 85 років, тому висновки щодо клініко-морфологічних особливостей ПК у дорослих пацієнтів будуть уточнені пізніше, коли особи, народжені після аварії, стануть старшими.

\section{Висновки}

1. У дітей та підлітків з досліджуваної когорти пацієнтів, прооперованих в Інституті ендокринології та обміну речовин імені В. П. Комісаренка за період з 1995 по 2014 р., частіше, ніж у дорослих, реєстрували більш агресивні ПК ЩЗ без принципового зв'язку з датою їх народження - до чи після аварії на ЧАЕС.

2. Частота мультифокальних ПК і карцином категорії N1ab нижча у дітей та підлітків, які народилися після аварії на ЧАЕС, у порівнянні з пацієнтами того ж віку, які народилися до аварії.

3. Частота ПК категорії N1ab i пухлин з інтратиреоїдною інвазією, а також частота виявлення високого ризику виникнення рецидиву виявилися вищими у дорослих пацієнтів, які народилися після аварії, у порівнянні з пацієнтами, які були дорослими на момент аварії на ЧАЕС, що потребує уточнення в подальших дослідженнях із залученням груп пацієнтів, репрезентативних за віком.

\section{Підтвердження}

Фінансування. Робота $є$ фрагментом НДР «Розробка індивідуальних алгоритмів хірургічного лікування пухлин щитоподібної залози, надниркових залоз, первинного та вторинного гіперпаратиреозу». Фінансування за рахунок державного бюджету.

Інформація про особистий внесок авторів. Коваленко А. Е. - мета, концепція та дизайн дослідження; Гуда Б. Б. - створення когорти, статистичне опрацювання результатів, аналіз даних літератури та власних, написання тексту статті. Всі автори прочитали і схвалили остаточний варіант рукопису.

Конфлікт інтересів. Автори, які взяли участь в цьому дослідженні, декларують відсутність конфлікту інтересів щодо цього рукопису.

Згода на публікацію. Всі автори дали згоду на публікацію цього рукопису.

\section{References}

1. Bogdanova T, Zurnadzhy L, LiVolsi V, Williams D, Ito M, Nakashima M, Thomas G. Thyroid cancer pathology in Ukraine after Chernobyl In: Thyroid cancer in Ukraine after Chernobyl: dosimetry, epidemiology, pathology, molecular biology. NASHIM: IN-TEX, Nagasaki, Japan. 2014; 65-108.

2. Furukawa K, Preston D, Funamoto S, Yonehara S, Ito M, Tokuoka S, et al. Long-term trend of thyroid cancer risk among Japanese atomic-bomb survivors: 60 years after exposure. Int J Cancer 2013 Mar; 132(5):12226. doi: 10.1002/ijc.27749. 
3. Gerasimov G, Figge D. Chernobyl: twenty years later. Klin Eksperim. Tireoidologija 2006;2(2):5-14. [In Russian].

4. Tronko M, Bogdanova T, Voskoboynyk, Zurnadzhy L, Shpak V, Gulak L. Radiation induced cancer: fundamental and applied aspects. Exp Oncol. 2010;32(3):200-4. PMID: 21403618.

5. LiVolsi V, Abrosimov A, Bogdanova T, Fadda G, Hunt J, Ito M. et al. The Chernobyl thyroid cancer experience: pathology. Clin Oncol (R Coll Radiol). 2011; 23(4): 261-7. doi: 10.1016/j.clon.2011.01.160.

6. Tronko M, Shpak V, Bogdanova T, Saenko V, Yamashita Sh. Epidemiology of thyroid cancer in Ukraine after Chernobyl. In: Thyroid cancer in Ukraine after Chernobyl: dosimetry, epidemiology, pathology, molecular biology. NASHIM: IN-TEX, Nagasaki, Japan. 2014;39-64.

7. Dal Maso L, Bosetti C, La Vecchia C, Franceschi S. Risk factors for thyroid cancer: an epidemiological review focused on nutritional factors. Cancer Causes Control. 2009;20(1):75-86. doi: 10.1007/s10552008-9219-5.

8. Davies L, Welch H. Thyroid cancer survival in the United States: observational data from 1973 to 2005. Arch Otolaryngol Head Neck Surg. 2010;136(5):440-4. doi: 10.1001/archoto.2010.55.

9. Hampson S, Stephens D, Wasserman J. Young age is associated with increased rates of residual and recurrent paediatric differentiated thyroid carcinoma. Clin Endocrinol (Oxf). 2018;89(2):212-8. doi: 10.1111/ cen. 13720 .

10. Palaniappan R, Krishnamurthy A, Rajaraman S, Kumar R. Management outcomes of pediatric and adolescent papillary thyroid cancers with a brief review of literature. Indian J Cancer. 2018;55(1):105-10. doi: 10.4103/ijc.IJC_486_17.
11. Azhar Y, Achmad D, Lukman K, Hilmanto D. Pediatric differentiated thyroid carcinoma risk factor for analysis for disease free survival. Indian J Med Paediatr Oncol. 2018;39(2):153-8. doi: 10.4103/ijmpo.ijmpo_70_17.

12. Zirilli G, Cannavò L, Vermiglio F, Violi M, Luca F, Wasniewska M. Differentiated thyroid carcinoma presentation may be more aggressive in children and adolescents than in young adults. Ital J Pediatr. 2018;44(1):13. doi: 10.1186/s13052-018-0455-3.

13. Guda B, Kovalenko A, Bolgov M, Taraschenko Yu, Mykhailenko N. Main prognostic factors for well differentiated thyroid cancer: Analis of combined patients treatment results during 20 years after surgery. Thyroid Disorders Ther. 2018;7(1):228. doi: 10.4172/2167-7948.1000228.

14. Bogdanova T, Saenko V, Brenner A, Zurnadzhy L, Rogounovitch T, Likhtarov I, et al. Comparative histopathologic analysis of "radiogenic" and "sporadic" papillary thyroid carcinoma: Patients born before and after the Chernobyl accident. Thyroid. 2018;28(7):880-90. doi: 10.1089/thy.2017.0594.

15. Tuttle R, Vaisman F, Tronko M. Clinical presentation and clinical outcomes in Chernobyl-related pediatric thyroid cancers: what do we know now? What can we expect in the future? Clin Oncol (R Coll Radiol). 2011;23(4):268-75. doi: 10.1016/j.clon.2011.01.178.

Надійшла 19.02.19 